\title{
Different fertilizer types affected nitrogen and carbon cycling in eroded and colluvial soils of Southern Ecuador
}

\author{
Etienne Bahr ${ }^{1^{*}}$, Ute Hamer ${ }^{2}$, Diego Chamba Zaragocin ${ }^{3}$, Franz Makeschin $^{1}$ \\ ${ }^{1}$ Institute of Soil Science and Site Ecology, Dresden University of Technology, Dresden, Germany; \\ *Corresponding Author: etienne.bahr@tu-dresden.de \\ ${ }^{2}$ Institute of Landscape Ecology, University of Muenster, Muenster, Germany \\ ${ }^{3}$ Departamento de Ciencias Agropecuarias y Alimentos, Universidad Técnica Particular de Loja, Loja, Ecuador
}

Received 8 October 2013; revised 12 November 2013; accepted 23 November 2013

Copyright (C) 2013 Etienne Bahr et al. This is an open access article distributed under the Creative Commons Attribution License, which permits unrestricted use, distribution, and reproduction in any medium, provided the original work is properly cited.

\section{ABSTRACT}

A tropical smallholder cash crop farming system in a semi-arid Inter-Andean valley of Ecuador was investigated. Intensive irrigated agriculture with up to $400 \mathrm{~kg}$ of urea-N fertilization $\mathrm{ha}^{-1} \cdot \mathrm{a}^{-1}$ prevails in colluvial sites whereas urea application in the steep eroded sites is lower. Farmers did recently introduce manure to partly replace urea fertilization. Knowledge about the effects of mineral and organic fertilizers on nitrogen and carbon cycling needs to be improved to maintain sustainable agriculture in the research area. Therefore, a laboratory incubation experiment was conducted to investigate effects of urea and guinea pig manure on microbial activity of colluvial foot slope and eroded upper slope soils. Soil samples were treated with $200 \mathrm{~kg} \cdot \mathrm{N} \cdot \mathrm{ha}^{-1}$ either applied as urea, guinea pig manure or a combination of both and compared to a control. Urea fertilizer was labeled with ${ }^{15} \mathrm{~N}$ to trace its fate. Microbial biomass and basal respiration were determined in different time intervals. Urea fertilization induced an acceleration of soil organic matter (SOM) mineralization (positive priming effect) in the first seven days of incubation. The combined fertilization served as a positive alternative to the present urea management since it increased the amount of $\mathrm{mi}-$ crobial biomass and provided mineral nitrogen for immediate plant uptake. Moreover, low recovery rates suggested an immobilization of fertilized nitrogen into the microbial biomass inducing an efficient and sustained nutrient release throughout the entire growing season.
SOM stocks in colluvial soils were $40 \%$ below those of eroded soils which was partly due to the positive priming effect after urea fertilization. Microbial activity and efficiency were not reduced by soil erosion.

Keywords: Fertilization; ${ }^{15} \mathrm{~N}$-Labeled Urea; Guinea Pig Manure; Erosion; Priming Effect; Soil Organic Matter

\section{INTRODUCTION}

Management systems are needed which sustain agriculture for future generations. This requires the maintenance of soil fertility [1] characterized as the ability of the soil to support plant growth by providing specific physical, chemical and biological needs [2]. Negative changes in soil fertility are in turn defined by a reduction of its productivity and ecosystem functions [3] and can be caused by various soil degradation processes such as nutrient depletion, reduction in humus quality and quantity [4] and erosion [5]. Studies in the Ecuadorian Andes revealed large erosion losses in agricultural areas [6] which left little arable soil particularly in the Inter-Andean basin [7]. In addition to soil erosion, nutrient depletion is regarded as major constraint in sustainable food production in smallholder farming systems in the tropics [8] and poses a threat to a sustainable livelihood development [9]. Erosion can intensify soil nutrient depletion and was the main cause for the latter in Ethiopia [10]. Human-induced nutrient depletion is generally caused by declining nutrient stocks due to insufficient replenishment after nutrient mining [11] and was reported for several areas in Ecuador [12,13]. Particularly in developing countries, replenishment of nutrients is mainly based on 
the application of mineral $\mathrm{N}$-fertilizers instead of a correctly proportioned NPK fertilization [14]. This has often led to the exhaustion of other nutrient elements [15]. Hence, there is a general consent about the need for an integrated nutrient management which would ensure nutrient supply for plant growth and at the same time reduce adverse environmental impacts of agricultural fertilizers [16].

Besides fertilization, a key factor in maintaining crop production and preventing nutrient depletion is soil organic matter (SOM) and therefore, a steady replenishment of organic resources is essential [17]. Especially in smallholder farms in the tropics, short-term nutrient availability and long-term maintenance of SOM depend crucially on organic amendments [18]. Their application induces long-term increases in soil organic carbon (SOC), total nitrogen $(\mathrm{TN})$ and microbial biomass carbon (MBC) [2] and a sustainable release of nutrients after immobilization into the soil microbial biomass (SMB) [19].

The microbial activity is usually enhanced after the addition of easily available carbon substrate which may also induce the acceleration of SOM mineralization. These strong short-term changes in the turnover of SOM after soil treatment are called priming effects (PEs) [20]. For the investigation of these effects, studies with ${ }^{15} \mathrm{~N}$ isotopes have been implemented widely to distinguish between soil and fertilizer derived $\mathrm{N}$ fractions [21-23]. Acceleration of SOM mineralization was found after urea addition for humid pasture agroecosystems in Ecuador $[24,25]$ but results for semi-arid agroecosystems of this area did not exist. Moreover, effects of non-organic (ammonium nitrate)/synthetic (urea) and organic fertilization on SOM dynamics in agricultural soils of dry tropical regions were ambiguous reporting SOM increases and decreases [26-28].

The Andes are characterized by a large heterogeneity of biophysical conditions and agricultural land use systems. Hence, in a rather small area multifaceted land use forms can be found [29]. The landscape of the semi-arid research area in Southern Ecuador is characterized by colluvial foot slope and eroded upper slope soils. Irrigated agriculture in smallholder farming systems has been practiced for almost 100 years. Farm surveys revealed large $\mathrm{N}$-fertilizer applications of up to 400 $\mathrm{kg} \cdot \mathrm{ha}^{-1} \cdot \mathrm{a}^{-1}$ in annual crops, which in the past were exclusively applied as urea. However, P and K-fertilization is hardly practiced [12] and crop residues are usually burned. Strategy programs and workshops induced by the government and the current research led to the establishment of small farm animal management. As a consequence, farmers did recently start to use a combined fertilization (synthetic + organic fertilizer) and partially replace urea with guinea pig (Cavia porcellus) or poultry manure. In contrast, indigenous people of the Saraguro,
$50 \mathrm{~km}$ north of the research area, have been using guinea pigs for several hundred years as a meat resource and applied the collected manure to their fields. Guinea pigs were also the scope of a few research studies about bacterial population dynamics [30], in pest control [31] or for heating purposes [32]. However, to the authors knowledge no studies exist that investigated the impact of guinea pig manure on microbial activity although this has been done in numerous studies for other manures in the dry tropics [33-35].

To maintain sustainable production in the semi-arid Andes of Southern Ecuador knowledge about organic and mineral fertilizers and their effects on nitrogen and carbon cycling has to be increased. Hence, the main objective of the research was to investigate fertilization effects of urea and guinea pig manure on microbial activity (net $\mathrm{N}$ mineralization and basal respiration) in eroded upper slope and colluvial foot slope soils. ${ }^{15} \mathrm{~N}$-labeled urea was used to distinguish between soil and urea-derived $\mathrm{N}$ in different mineral $\mathrm{N}$ fractions during mineralization.

It was hypothesized that:

1) Fertilization solely with urea induces an acceleration of SOM mineralization (positive PE).

2) Fertilization with manure can support long-term nutrient availability due to $\mathrm{N}$ immobilization into the SMB.

3) As a result of erosion upper slope soils contain less SOM and SMB and therefore, have a lower mineralization potential.

\section{METHODOLOGY}

\subsection{Site Description and Sampling}

The present study was implemented in the semi-arid (two to four humid months from January to April) Inter-Andean Sierra $\left(04^{\circ} 05^{\prime} \mathrm{S}\right.$ and $\left.79^{\circ} 18^{\prime} \mathrm{W}\right)$ of southern Ecuador in El Tambo. This village lies within the western escarpments of the Cordillera Real, about $20 \mathrm{~km}$ southwest of the provincial capital Loja. The climate is characterized by a mean annual air temperature of $23.7^{\circ} \mathrm{C}$ and a mean annual rainfall of $383 \mathrm{~mm}$ [36]. Smallholder farms with an average farm size between one and three hectares are typical in the region. All farms investigated cultivate cash crops such as tomato, pepper, cucumber and maize which are the main source of income. Land-use characteristics in the study area differ between agricultural areas at the colluvial foot slopes and those located on the steep eroded slopes (Figure 1). Colluvial foot slopes are managed in an irrigation system with high urea application rates and two to three harvests per year. In contrast, agriculture in eroded sites is mainly performed during the rainy season and fertilizer application rates are low. However, management of harvest residues 


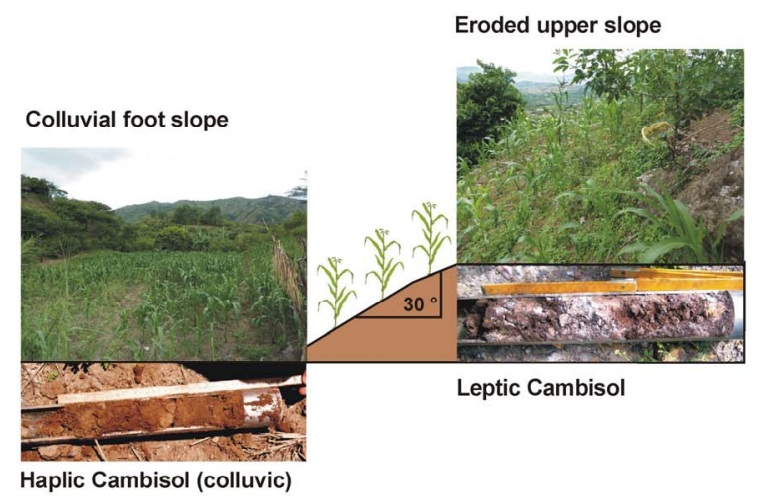

\begin{tabular}{|c|c|c|}
\hline \multicolumn{3}{|c|}{ Land-use characteristics } \\
\hline & Colluvial site & Eroded site \\
\hline $\begin{array}{l}\text { Management } \\
\text { system }\end{array}$ & Intensive & Extensive \\
\hline Cultivation & $\begin{array}{l}2-3 \text { harvests throughout } \\
\text { the year }\end{array}$ & $\begin{array}{l}\text { Only during rainy season from } \\
\text { January to April }\end{array}$ \\
\hline Crop rotation & $\begin{array}{l}\text { Rotation of maize- } \\
\text { cucumber-pepper-tomato }\end{array}$ & Only maize \\
\hline $\begin{array}{l}\text { Harvest residue } \\
\text { management }\end{array}$ & $\begin{array}{l}\text { Burning or removal of the } \\
\text { entire plant }\end{array}$ & Removal of the entire plant \\
\hline Fertilization & Up to $400 \mathrm{~kg} \cdot \mathrm{N} \cdot \mathrm{ha} \mathrm{a}^{-1} \cdot \mathrm{a}^{-1}$ & Between $100-200 \mathrm{~kg} \cdot \mathrm{N} \cdot \mathrm{ha}^{-1} \cdot \mathrm{a}^{-1}$ \\
\hline Plowing & $\begin{array}{l}\text { Mechanized to a depth } \\
\text { of } 30 \mathrm{~cm}\end{array}$ & No \\
\hline Irrigation & Open channels & No \\
\hline
\end{tabular}

Figure 1. Slope positions, soil augers of the main soil types [37] and basic land-use characteristics of colluvial and eroded sites.

is equal in both locations since nutrients are removed by either burning or harvesting of the total plant. Locations in an upper slope position are subject to erosion especially during the rainy months. This process is accelerated by the cultivation of maize and the lack of soil conservation techniques. Detached particles are transported downslope and deposited at the foot of the slope and hence, resulting in the formation of colluvial soils (Figure 1).

Field observations and surveys resulted in the selection of the study sites at ten different farms in 2010. Five of them were in the location of colluvial foot slopes (average inclination of $2^{\circ}$ ) with Haplic Cambisols (colluvic, eutric) as the main soil types (Figure 1). The other five sites were located at the eroded upper slopes (average inclination of $30^{\circ}$ ) where Leptic Cambisols (eutric) are the dominant soil types [37]. Parent material of all Cambisols was the magmatic vulcanite dacite [38]. At the time of sampling, maize (Zea mays L.) was cultivated in all sites. For each site a composite soil sample was taken to a depth of $10 \mathrm{~cm}$ of the mineral soil from 10 random points using a soil auger (diameter: $5.5 \mathrm{~cm}$ ). Directly after sampling stones and roots were removed.

\subsection{Analysis of Soil Physical and Chemical Properties}

For the determination of the soil moisture content one sample of each site was oven-dried at $105^{\circ} \mathrm{C}$. To determine SOC and TN, an aliquot of each soil sample was dried at $40^{\circ} \mathrm{C}$ and finely ground (CNS-analyser, Vario EL, Heraeus). SOM was calculated by multiplying SOC with 1.72 [39]. The cation exchange capacity was analyzed with $\mathrm{BaCl}_{2}$-TEA [40]. The procedure of McKeague and Day [41] was used for the determination of the iron dithionite content. Plant available $\mathrm{PO}_{4}-\mathrm{P}$ was determined with $\mathrm{NH}_{4}-\mathrm{F}$ extraction [42]. The $\mathrm{pH}$ was measured potentiometrically in field moist soils at a 1:2.5 soil/water ratio in deionized water at days 0,7 and 28 . For the determination of the fine soil density, volumetric dried soil samples were sieved through a $2 \mathrm{~mm}$ mesh size. Nutrient element stocks $\left[\mathrm{Mg} \cdot \mathrm{ha}^{-1}\right]$ were calculated using the fine soil density [43]. Soil texture was determined by sieving and sedimentation [44].

\subsection{Fertilization Experiment}

A laboratory incubation experiment with a randomized block design was conducted for 28 days at $22^{\circ} \mathrm{C}$ to investigate the impact of different fertilizer treatments (urea, guinea pig manure and a combination of both) on microbial activity. Maximum yearly $\mathrm{N}$-fertilizer application rates in the research area amount to $400 \mathrm{~kg} \cdot \mathrm{N} \cdot \mathrm{ha}^{-1}$ and are applied in two or three dosages. Hence, the amount of fertilizer-N applied in the incubation experiment was adjusted to $200 \mathrm{~kg} \cdot \mathrm{N} \cdot \mathrm{ha}^{-1}$ which is representative for a single fertilization event. This amount is also characteristic of intensively managed and irrigated agricultural soils $[45,46]$. Therefore, $0.21 \mathrm{mg} \cdot \mathrm{N} \cdot \mathrm{g}^{-1}$ dry weight $(\mathrm{dw})$ soil was added to the field moist soil samples from colluvial and eroded soils. Soil moisture was maintained at field condition throughout the incubation. Samples of the same soil were treated with equivalent $\mathrm{N}$-amounts as

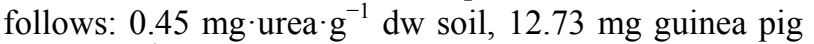
manure $\cdot \mathrm{g}^{-1} \mathrm{dw}$ soil, $0.23 \mathrm{mg}$ urea $+6.37 \mathrm{mg}$ guinea pig manure $\cdot \mathrm{g}^{-1} \mathrm{dw}$ soil and were compared to a non-treated control soil. Guinea pig manure is referred to as manure in the following chapters. To determine the impact of urea on the nitrogen mineralization, ${ }^{15} \mathrm{~N}$-labeled ureasolution was used $(0.5 \mathrm{ml}$ of 0.8 atom\%). The same amount of deionized water was added to control and manure-treated samples. The $\delta^{15} \mathrm{~N}$-values in control soils were 0.368 atom $\%$ and amounted to 0.371 atom $\%$ in the manure. Therefore, an interference of the manure nitrogen in the ${ }^{15} \mathrm{~N}$ values for the combined fertilization could be excluded.

\subsection{Microbial Activity and Biomass}

Cumulative microbial respiration was measured as evolved $\mathrm{CO}_{2}$ in $0.05 \mathrm{M} \mathrm{NaOH}$ at different time intervals 
(for days 0 - 1, 1 - 7, 7 - 14, 14 - 21, 21 - 28) by adding $\mathrm{BaCl}_{2}$ and subsequent titration with $0.05 \mathrm{M} \mathrm{HCl}$ against phenolphthalein. Results were then converted into $\mathrm{CO}_{2}-\mathrm{C}$ $\left[\mathrm{mg} \cdot \mathrm{g}^{-1} \mathrm{SOC}+\mathrm{g}^{-1}\right.$ fertilizer $\left.\mathrm{C} \cdot \mathrm{d}^{-1}\right]$ in order to facilitate the interpretation on the basis of available carbon since fertilizers contained different amounts of C. Hamer et al. [25] found for South Ecuadorian pasture soils that one day after application of ${ }^{14} \mathrm{C}$-labeled urea already $82 \%$ of the added urea-C had been mineralized. Even after 28 days of incubation mineralized ${ }^{14} \mathrm{C}$-labeled urea did not exceed $82 \%$. Thus, in the present study a PE was only considered if the $\mathrm{CO}_{2}$ respiration of urea-treated soils exceeded that of control soils by more than $82 \%$ of the initially applied urea-C which is equivalent to $73.8 \mathrm{mg}$ urea-C $\cdot \mathrm{kg}^{-1}$.

The chloroform-fumigation-extraction method by Vance et al. [47] was used to determine MBN and MBC at incubation days 0 (15 minutes after fertilizer treatment), 7, 14 and 28. Chloroform fumigated (24 h) and non-fumigated soil samples (20 $\mathrm{g} \mathrm{dw}$ equivalent) were extracted with $100 \mathrm{ml} 0.5 \mathrm{M} \mathrm{K}_{2} \mathrm{SO}_{4}$ and filtered. TN and organic $\mathrm{C}$ of the filtrate aliquots were analyzed instantly with a multi-NC-analyzer (Analytik Jena, Germany). For the calculation of $\mathrm{MBC}$ and microbial biomass nitrogen (MBN) the difference in $\mathrm{C}$ and $\mathrm{N}$ concentration between fumigated and non-fumigated extracts was multiplied with a $\mathrm{k}_{\mathrm{EC}}$ of 0.43 [48] and a $\mathrm{k}_{\mathrm{EN}}$ of 0.45 [49], respectively. The microbial metabolic quotient $q \mathrm{CO}_{2}\left[\mathrm{~g} \mathrm{CO}_{2-}\right.$ $\left.\mathrm{C} \cdot \mathrm{kg}^{-1} \mathrm{MBC} \cdot \mathrm{h}^{-1}\right]$ was calculated according to Anderson $\&$ Domsch [50].

For the determination of total inorganic N (TIN) soil samples $(30 \mathrm{~g})$ were extracted with $120 \mathrm{ml} 0.1 \mathrm{M} \mathrm{KCl} \mathrm{(2}$ $\mathrm{h}$ shaking at $180 \mathrm{rpm}$ ) and filtrated (Schleicher \& Schuell No. 2095 1/2). The amounts of TIN in the extracts were subsequently measured by a continuous-flow auto analyzer (Skalar Analytik GmbH, Erkelenz, Germany). Dissolved organic carbon (DOC) and total dissolved nitrogen (TDN) were determined using a multi-NC-analyzer for liquids (Analytik, Jena, Germany). Dissolved organic nitrogen (DON) was calculated by subtraction of TIN from TDN. The ${ }^{15} \mathrm{~N}$-diffusion procedure as described by Mulvaney et al. [51] was carried out in order to determine ${ }^{15} \mathrm{~N} /{ }^{14} \mathrm{~N}$ isotope ratios of $\mathrm{NO}_{3}-\mathrm{N}$ and $\mathrm{NH}_{4}-\mathrm{N}$ at days 0 (15 minutes after fertilizer treatment), 7, 14 and 28. ${ }^{15} \mathrm{~N}$-enrichment was determined in the dried filter paper disks by means of mass spectrometry (EA-IRMS Delta 2, Carlo Erba and Finnigan). PEs on $\mathrm{N}$ mineralization were calculated using the isotope signature of ${ }^{15} \mathrm{NH}_{4}-\mathrm{N}$ and ${ }^{15} \mathrm{NO}_{3}-\mathrm{N}$ of the soils treated with ${ }^{15} \mathrm{~N}$-labeled urea $(0.8$ atom\%). The proportion of $\mathrm{N}$ derived from soil $\left(N_{\text {soil-derived }}\right.$ in $\left.\mathrm{mg} \cdot \mathrm{kg}^{-1}\right)$ in the respective $\mathrm{N}$ fraction $\left(\mathrm{NH}_{4}-\mathrm{N}\right.$ or $\left.\mathrm{NO}_{3}-\mathrm{N}\right)$ was calculated as follows:

$$
\mathrm{N}_{\text {soil-derived }}=\frac{\mathrm{N}_{+ \text {urea }} \times\left(\text { atom } \%_{\text {+urea }}-0.8 \text { atom } \%\right)}{-0.8 \text { atom } \%+\text { atom } \% \text { control }}
$$

Results for ${ }^{15} \mathrm{NH}_{4}-\mathrm{N}$ and ${ }^{15} \mathrm{NO}_{3}-\mathrm{N}$ were converted into $\mathrm{g} \cdot \mathrm{kg}^{-1} \mathrm{TN}$ to take different initial TN contents of colluvial and eroded soils into account.

\subsection{Statistical Analyses}

Statistical analyses were performed with Statistica 9.0. Data were examined for homogeneity of variance using the Levene test and normal distribution was verified with the Kolmogorov-Smirnov test prior to analysis. $\mathrm{CO}_{2}-\mathrm{C}$ production rates per day, $\mathrm{MBC}, \mathrm{MBN}, \mathrm{DOC}, \mathrm{pH}, q \mathrm{CO}_{2}$, $\mathrm{NH}_{4}-\mathrm{N}$ and $\mathrm{NO}_{3}-\mathrm{N}$ were analyzed by repeated measures (RM) two-way factorial ANOVA with the factors "treatment" (control, urea, guinea pig manure and combined fertilization) and "location" (eroded and colluvial site). In the case of significant interaction of the factors, interpretation of the main effects was assessed on the basis of separate analyses. Significant differences were tested with Tukey's test using a probability level of $p<0.05$ unless otherwise stated. Pearson correlation coefficients were calculated to test the relationships between variables. Principal Component Analysis (PCA) with the CANOCO 4.5 program [52] was used to assess the impact of fertilization and location on microbial properties (response variables: $\mathrm{MBC}, \mathrm{MBN}$ and respiration) at day 0 and 28. Soil physical and chemical variables comprised DOC, $\mathrm{NH}_{4}-\mathrm{N}, \mathrm{NO}_{3}-\mathrm{N}$, DON, $\mathrm{PO}_{4}-\mathrm{P}$ and $\mathrm{H}_{3} \mathrm{O}^{+}$and were projected into the ordination plot to assist in interpreting microbial activity related processes. Mean values and standard error were calculated for each category (site and fertilizer treatment) and projected into the ordination plot.

\section{RESULTS}

\subsection{Effects on Soil Physical and Chemical Properties}

SOM stocks differed significantly between eroded and colluvial soils and were 1.6 times higher in eroded soils despite lower clay contents (Table 1). The soil texture and the ratio of $\mathrm{Fe}_{\mathrm{dith}} / \mathrm{Fe}_{\text {tot }}$ which can be defined as an indicator for the extent of pedogenesis [53] were in the same order of magnitude for eroded and colluvial soils indicating comparable site conditions. Soil $\mathrm{pH}, \mathrm{C} / \mathrm{N}$ ratio, $\mathrm{CEC}$ and $\mathrm{PO}_{4}-\mathrm{P}$ content were in the same order of magnitude for eroded and colluvial soils (Table 1). For soil $\mathrm{pH}$, variation due to incubation day was greater than due to significant treatment effects (Table 2). Manure and combined-treated soils showed significantly higher $\mathrm{pH}$ values $(p<0.001)$ than urea treated soils at day 0 . This difference leveled off until day 28. Electrical conductivity of the irrigation water and the soils (data not shown) pointed out that soils were not affected by salinization. 
Table 1. Soil physical and chemical characteristics of foot slope and upper slope soils $(0-10 \mathrm{~cm}$ depth) in the research area (mean, $\mathrm{SE}$ in parenthesis, $\mathrm{n}=5$ ).

\begin{tabular}{ccccccccccc}
\hline & $\begin{array}{c}\text { Fine Soil } \\
\text { Density }\end{array}$ & $\mathrm{pH}\left(\mathrm{H}_{2} \mathrm{O}\right)$ & $\begin{array}{c}\mathrm{SOC} \\
{\left[\mathrm{g} \cdot \mathrm{kg}^{-1}\right]}\end{array}$ & $\begin{array}{c}\mathrm{SOM} \\
{\left[{\left.\mathrm{Mg} \cdot \mathrm{ha}^{-1}\right]}^{\mathrm{C}}\right.}\end{array}$ & $\mathrm{C} / \mathrm{N}$ & $\begin{array}{c}\mathrm{PO}_{4}-\mathrm{P} \\
{\left[\mathrm{mg}_{\mathrm{kg}}\right]}\end{array}$ & $\begin{array}{c}\mathrm{CEC} \\
{\left[\mathrm{cmol}_{\mathrm{c}} \cdot \mathrm{kg}^{-1}\right]}\end{array}$ & $\begin{array}{c}\text { Silt } \\
{[\%]}\end{array}$ & $\begin{array}{c}\mathrm{Clay}^{2} \\
{[\%]}\end{array}$ & $\mathrm{Fe}_{\text {dith }} / \mathrm{Fe}_{\text {tot }}$ \\
\hline Colluvial site & $0.60(0.05)$ & $6.9(0.1)$ & $14.5(2.2)$ & $14.4(0.9)^{\mathrm{a}}$ & $11.6(0.4)$ & $20.4(2.0)$ & $47.6(5.8)$ & $30.6(3.3)$ & $38.1(1.7)$ & $0.17(0.03)$ \\
Eroded site & $0.68(0.07)$ & $6.8(0.2)$ & $20.2(3.1)$ & $23.6(4.1)^{\mathrm{b}}$ & $11.8(0.7)$ & $17.8(5.2)$ & $38.7(5.8)$ & $33.3(2.8)$ & $32.1(5.3)$ & $0.20(0.03)$ \\
\hline
\end{tabular}

Statistical significance at the 0.05 level is indicated by different letters.

Table 2. Results of RM two-way factorial ANOVA (F-values and significance) testing the effects of treatment and location at different days of incubation on $\mathrm{MBC}, \mathrm{MBC} / \mathrm{SOC}, \mathrm{MBN}$ (Error degrees of freedom $=96$ ), DOC (Error degrees of freedom $=72$ ), $q \mathrm{CO} 2$ $($ Error degrees of freedom $=62)$ and $\mathrm{pH}($ Error degrees of freedom $=64)$.

\begin{tabular}{|c|c|c|c|c|c|c|c|c|}
\hline & \multirow{2}{*}{$\mathrm{DF}$} & \multicolumn{4}{|c|}{ F-values } & \multirow{2}{*}{ DF } & \multicolumn{2}{|c|}{ F-values } \\
\hline & & $\mathrm{MBC}$ & $\mathrm{MBC} / \mathrm{SOC}$ & $\mathrm{MBN}$ & DOC & & $q \mathrm{CO}_{2}$ & $\mathrm{pH}$ \\
\hline Treatment & 3 & $11.51^{* * *}$ & $7.24^{* * *}$ & $22.18^{* * *}$ & $82.58^{* * *}$ & 3 & $185.27^{* * *}$ & $3.96^{*}$ \\
\hline Location & 1 & $14.56^{* * *}$ & 0.50 & $16.26^{* * *}$ & 0.02 & 1 & $21.44^{* * *}$ & 0.85 \\
\hline Treatment $\times$ Location & 3 & 0.19 & 0.15 & 0.21 & 1.54 & 3 & $3.79^{*}$ & 0.00 \\
\hline Incubation Day & 3 & $34.35^{* * *}$ & $30.62^{* * *}$ & $18.78^{* * *}$ & $397.18^{* * *}$ & 2 & $472.19^{* * *}$ & $128.47^{* * *}$ \\
\hline Treatment $\times$ Incubation Day & 9 & $13.05^{* * *}$ & $10.32^{* * *}$ & $20.12^{* * *}$ & $83.28^{* * *}$ & 6 & $92.22^{* * *}$ & $110.29^{* * *}$ \\
\hline Location $\times$ Incubation Day & 3 & 1.27 & $3.83^{*}$ & $3.38^{*}$ & 2.45 & 2 & $8.07^{* * *}$ & 1.29 \\
\hline $\begin{array}{l}\text { Treatment } \times \text { Location } \\
\times \text { Incubation Day }\end{array}$ & 9 & $3.81^{* * *}$ & $3.08^{* *}$ & $6.20^{* * *}$ & 1.48 & 6 & 1.34 & 0.54 \\
\hline
\end{tabular}

${ }^{*},{ }^{* *},{ }^{* * *}$ show statistical significance at the $0.05,0.01$ and 0.001 level, respectively.

\subsection{Measured Soil Nitrogen and Carbon Pools}

Large differences in the $\mathrm{NH}_{4}-\mathrm{N}$ and $\mathrm{NO}_{3}-\mathrm{N}$ contents were observed within the fertilizer treatments and the slope position during the 28 day incubation experiment. $\mathrm{NH}_{4}-\mathrm{N}$ in urea treated soils tripled in the first seven days of the incubation from $14.6( \pm 1.9 \mathrm{SE})$ and $21.8( \pm 1.7 \mathrm{SE})$ to $39.5( \pm 7.3 \mathrm{SE})$ and $64.9 \mathrm{mg} \cdot \mathrm{kg}^{-1}( \pm 7.7 \mathrm{SE})$ in colluvial and eroded soils, respectively. Until the end of incubation $\mathrm{NH}_{4}-\mathrm{N}$ decreased to $1.1( \pm 0.1 \mathrm{SE})$ and 3.4 $\mathrm{mg} \cdot \mathrm{kg}^{-1}( \pm 1.5 \mathrm{SE})$, respectively and was in the same order as for the other treatments. However, in soils of the control, manure or combined treatment $\mathrm{NH}_{4}-\mathrm{N}$ contents never exceeded $4 \mathrm{mg} \cdot \mathrm{kg}^{-1}$ throughout the incubation. 28 days after treatment with urea, $\mathrm{NO}_{3}-\mathrm{N}$ in colluvial and eroded soils had steadily increased to 224.1 ( $\pm 4.2 \mathrm{SE}$ ) and $231.0 \mathrm{mg} \cdot \mathrm{kg}^{-1}( \pm 11.4 \mathrm{SE})$, respectively. An increase in $\mathrm{NO}_{3}-\mathrm{N}$ to $77.7( \pm 4.2 \mathrm{SE})$ and $104.2 \mathrm{mg} \cdot \mathrm{kg}^{-1}( \pm 7.7 \mathrm{SE})$ was also detected for colluvial and eroded soils treated with the combined fertilization whereas in manure treated soils $\mathrm{NO}_{3}-\mathrm{N}$ contents were negligible throughout the incubation never exceeding $2.2 \mathrm{mg} \cdot \mathrm{kg}^{-1}$.

DOC contents were in the same order of magnitude in colluvial and eroded soils at day 0 for all fertilizer treatments and ranged between 82.0 and $111.3 \mathrm{mg} \cdot \mathrm{kg}^{-1}$. However, in urea and combined treated soils DOC contents quickly decreased to less than $7.2( \pm 3.0 \mathrm{SE})$ and $18.0 \mathrm{mg} \cdot \mathrm{kg}^{-1}( \pm 2.6 \mathrm{SE})$, respectively, at day seven. In contrast, DOC contents in manure treated soils decreased considerably slower being significantly $(p<0.001)$ above those of the other treatments from day 7 on and still amounted to $27.1 \mathrm{mg} \cdot \mathrm{kg}^{-1}( \pm 4.2 \mathrm{SE})$ at day 28 .

MBC and MBN constantly decreased in urea treated soils from $418.1( \pm 43.9 \mathrm{SE})$ and $53.4 \mathrm{mg} \cdot \mathrm{kg}^{-1}( \pm 6.5 \mathrm{SE})$ at day 0 to $298.9( \pm 34.6 \mathrm{SE})$ and $43.5 \mathrm{mg} \cdot \mathrm{kg}^{-1}( \pm 5.9 \mathrm{SE})$ at day 28. In contrast, manure and combined treated soils showed an increase in the first 14 days of incubation of approximately $10 \%$ for MBC and MBN before decreasing to $513.5( \pm 27.6 \mathrm{SE}) / 444.7 \mathrm{mg} \cdot \mathrm{kg}^{-1}( \pm 34.8 \mathrm{SE})$ and $70.8( \pm 4.7 \mathrm{SE}) / 54.8 \mathrm{mg} \cdot \mathrm{kg}^{-1}( \pm 4.6 \mathrm{SE})$ at day 28 , respectively. The amount of MBC and MBN added by application of guinea pig manure was 153.7 and $15.8 \mathrm{mg} \cdot \mathrm{kg}^{-1}$, respectively and was half that amount for the combined treatment. The alteration in MBC and MBN between the various fertilizer treatments can therefore partially be explained by the application of guinea pig manure. Nonetheless, the difference of MBC and MBN in manure and combined compared to urea treated soils was higher than the amount of MBC and MBN added by the manure application throughout the incubation. This was also indicated by highly significant effects of the treatment on MBC and MBN (Table 2). Moreover, a highly significant effect of the incubation day on MBC and MBN was elucidated by decreasing versus unchanged amounts of $\mathrm{MBC}$ and MBN in urea treated versus manure and combined treated soils, respectively.

Significant effects of fertilizer treatment and incubation day were found for the $\mathrm{MBC} / \mathrm{SOC}$ ratio. This was 
illustrated by an increase of the $\mathrm{MBC} / \mathrm{SOC}$ ratio from $2.6 \%( \pm 0.39 \mathrm{SE})$ in urea-treated soils to $3.5 \%( \pm 0.23 \mathrm{SE})$ in manure-treated soils at day 0 . This difference was even more pronounced and highly significant $(p<0.001)$ after day 28 where the ratio had declined to $1.7( \pm 0.13$ $\mathrm{SE})$ and $3.3 \%( \pm 0.29 \mathrm{SE})$ in urea and manure-treated soils, respectively.

The metabolic quotient $q \mathrm{CO}_{2}$ exhibited wider ratios for colluvial soils compared to eroded soils for all treatments which was indicated by the significant effect of the location (Table 2). This was significant after manure and combined treatment for all days of incubation and at day 7 for urea treated soils $(p<0.05)$.

Interaction effects of treatment and location were only significant for $q \mathrm{CO}_{2}$ (Table 2). In contrast, interaction effects were always significant for treatment and incubation day which means that the effect of the independent variable treatment was affected by the incubation day. However, a three-way interaction, where the factors treatment and location were modified by incubation day, was only significant for MBC, MBC/SOC and MBN.

\subsection{Soil Nitrogen and Carbon Mineralization Rates}

The applied ${ }^{15} \mathrm{~N}$ labeled urea was used to determine its fate into the soil $\mathrm{NH}_{4}-\mathrm{N}$ and $\mathrm{NO}_{3}-\mathrm{N}$ fraction. A quicker turnover of the ${ }^{15} \mathrm{~N}$-labeled urea in colluvial soils was indicated by higher recovery rates for $\mathrm{NO}_{3}-\mathrm{N}$ at days 7 and 14 (Table 3). In contrast, the recovery rates in soils treated with the combined fertilization decreased after 14 days and never exceeded 50\% during incubation. This process seemed even more pronounced in colluvial soils which had a $10 \%$ lower total recovery rate.

$\mathrm{NH}_{4}-\mathrm{N}$ showed a distinct time pattern of the different treatments, meaning that urea served as a rapid ammonium source as opposed to manure-treated soils. The significant treatment effect (RM ANOVA; $\mathrm{F}_{3,32}=29.39$; $p<0.001$ ) was illustrated by strongly increasing $\mathrm{NH}_{4}-\mathrm{N}$ contents from day 0 to day 7 after treatment with urea whereas $\mathrm{NH}_{4}-\mathrm{N}$ contents decreased after manure and combined treatment. Immediately after urea addition (day 0 ), the amount of additionally released soil-derived $\mathrm{NH}_{4}-\mathrm{N}$ in urea-treated soils was 3.4 and $3.6 \mathrm{~g} \cdot \mathrm{kg}^{-1} \mathrm{TN}$ in colluvial and eroded soils, respectively (Figure 2(a)). PEs increased to 7.3 and $8.2 \mathrm{~g} \cdot \mathrm{kg}^{-1} \mathrm{TN}$ after 7 days. This change can be assigned to a positive PE, since MBN for the control and urea-treated soils were in the same order of magnitude throughout the incubation. An exchange of ${ }^{15} \mathrm{NH}_{4}$ with ${ }^{14} \mathrm{NH}_{4}$ to clay minerals should be minor as was shown by Hamer et al. [25] for South Ecuadorian soils.

$\mathrm{NO}_{3}-\mathrm{N}$ derived from the soil $\mathrm{N}$ pool was between 120 and $185 \%$ above those of the control soils at day 7 in urea as well as combined-treated colluvial and eroded soils. Since the PE of urea and combined-treated samples was in the same order of magnitude, the applied amount of urea in the combined treatment was sufficient to mineralize the easily available SOC. The positive PE increased steadily until day 28 in urea-treated soils whereas it remained on the same level after combined treatment (Figure 2(b)). However, soil and manure-derived $\mathrm{NO}_{3}-\mathrm{N}$ cannot be distinguished. Yet $\mathrm{NO}_{3}-\mathrm{N}$ contents in manure-treated soils were by far lower than those of the combined treatment. Therefore, it can be assumed that most of the additional nitrogen after combined treatment was soil-derived. As opposed to $\mathrm{NH}_{4}-\mathrm{N}, \mathrm{NO}_{3}-\mathrm{N}$ exhibited a significant location effect (RM ANOVA; $F_{1,28}$ $=16.74 ; p<0.001)$ and was significantly higher in colluvial sites compared to eroded sites.

Depending on fertilizer treatment and incubation day, the pattern of $\mathrm{CO}_{2}-\mathrm{C}$ release varied which was indicated by the significant interaction of treatment and incubation day (RM ANOVA; $\mathrm{F}_{12,124}=34.94 ; p<0.001$ ) (Figure 3). This was confirmed by the very sharp decrease in urea-treated soils after the first week of incubation when probably most of the urea-C had been mineralized [25].

Table 3. Rates of recovery [\%] for ${ }^{15} \mathrm{~N}$ labelled urea in colluvial and eroded sites treated with urea and combined fertilizer at day 0 (i.e. 15 minutes after urea treatment), 7, 14 and 28 (mean values, $\mathrm{SE}$ in parenthesis, $\mathrm{n}=5$ ).

\begin{tabular}{|c|c|c|c|c|c|c|c|}
\hline & \multirow{2}{*}{$\begin{array}{c}\text { Treatment } \\
\text { Day }\end{array}$} & \multicolumn{3}{|c|}{ Urea } & \multicolumn{3}{|c|}{ Combined fertilization } \\
\hline & & $\mathrm{NH}_{4}-\mathrm{N}$ & $\mathrm{NO}_{3}-\mathrm{N}$ & Total & $\mathrm{NH}_{4}-\mathrm{N}$ & $\mathrm{NO}_{3}-\mathrm{N}$ & Total \\
\hline \multirow{4}{*}{ 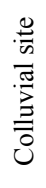 } & 0 & $4.9(0.8)$ & n.d. & $4.9(0.8)$ & $13.9(1.3)$ & n.d. & $13.9(1.3)$ \\
\hline & 7 & $15.0(3.1)$ & $49.8(4.7)$ & $64.8(2.1)$ & $0.8(0.2)$ & $47.7(2.4)$ & $48.5(1.8)$ \\
\hline & 14 & $0.5(0.1)$ & $71.7(1.2)$ & $72.2(1.1)$ & $0.0(0.0)$ & $33.6(2.4)$ & $33.6(2.4)$ \\
\hline & 28 & $0.0(0.0)$ & $80.4(1.1)$ & $80.4(1.2)$ & $0.0(0.0)$ & $36.0(3.1)$ & $36.0(3.1)$ \\
\hline \multirow{4}{*}{ 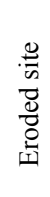 } & 0 & $7.7(0.8)$ & n.d. & $7.7(0.8)$ & $19.9(2.0)$ & n.d. & $19.9(2.0)$ \\
\hline & 7 & $24.2(3.4)$ & $39.4(5.5)$ & $63.6(2.9)$ & $2.0(0.4)$ & $48.5(5.1)$ & $50.5(4.0)$ \\
\hline & 14 & $5.8(2.3)$ & $63.1(6.2)$ & $68.9(3.6)$ & $0.0(0.0)$ & $43.6(3.8)$ & $43.6(3.8)$ \\
\hline & 28 & $0.7(0.2)$ & $79.5(4.2)$ & $80.2(3.8)$ & $0.0(0.0)$ & $49.4(3.7)$ & $49.4(3.7)$ \\
\hline
\end{tabular}




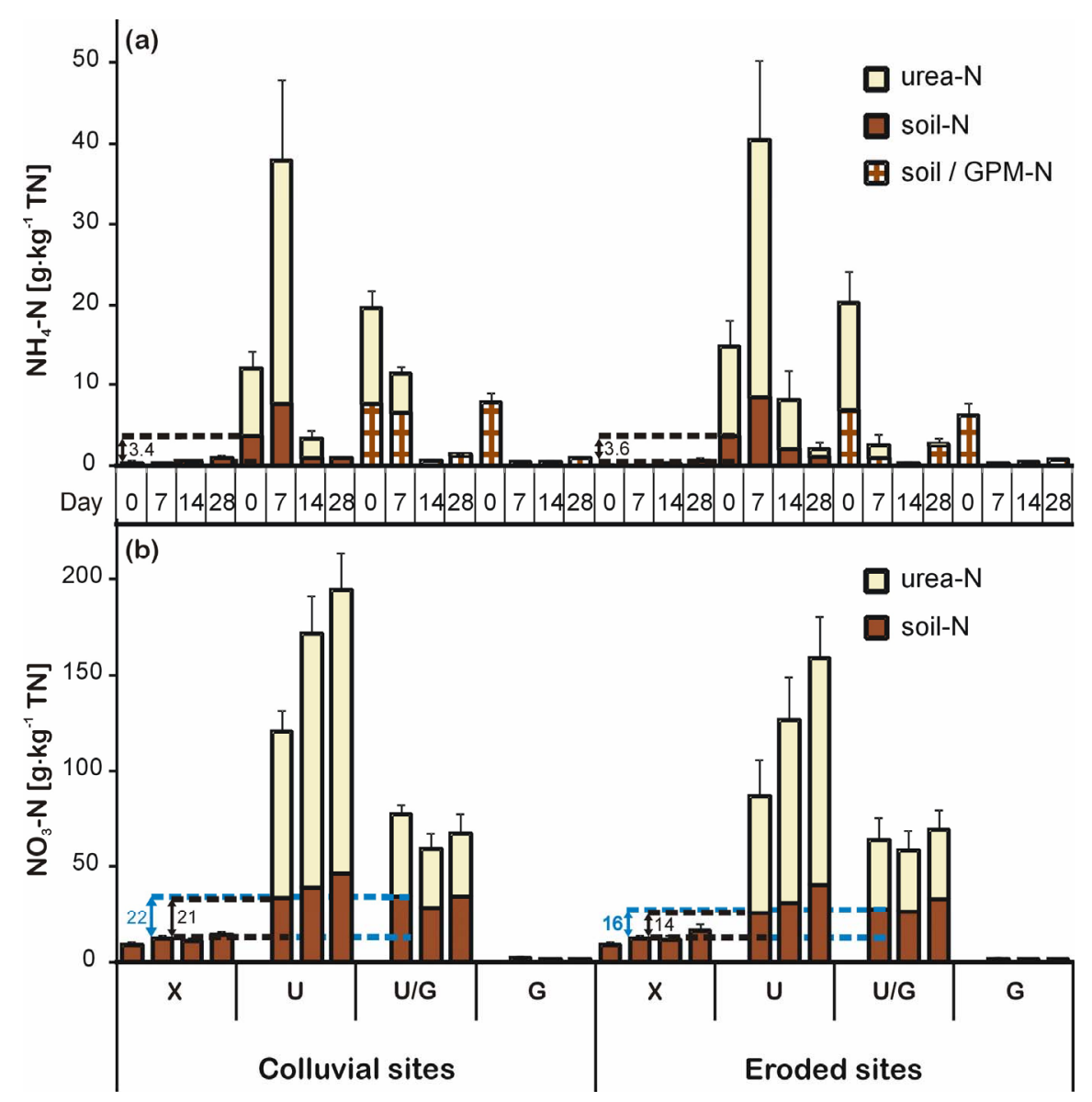

Figure 2. Amounts of soil-derived and urea-derived $\mathrm{NH}_{4}-\mathrm{N}$ (a) and $\mathrm{NO}_{3}-\mathrm{N}$ (b) (mean, bars represent $\mathrm{SE}, \mathrm{n}=5)$ in colluvial and eroded soils with different fertilizer treatments $(\mathrm{X}=$ control, $U=$ urea, $U / G=$ combined fertilization, $G=$ guinea pig manure). Numbers shown in the figure exemplify the amount of extra soil-derived (positive $\mathrm{PE}$ ) $\mathrm{NH}_{4}-\mathrm{N}$ at day 0 and $\mathrm{NO}_{3}-\mathrm{N}$ at day 7. Results (F-values and significance) of repeated measures two-way factorial ANOVA are shown which test the effects of treatment and location at different days of incubation on $\mathrm{NH}_{4}-\mathrm{N}$ and $\mathrm{NO}_{3}-\mathrm{N}$ (Error degrees of freedom (DF) $=96$ and 55, respectively; $\left.{ }^{*} p<0.05, \stackrel{* *}{p}<0.01, \stackrel{* * *}{p}<0.001\right)$.

In contrast, $\mathrm{C}$ mineralization in manure-treated soils was subject to a gradual decrease until the end of incubation. The $\mathrm{C}$ mineralization was significantly affected by the location (RM ANOVA; $\left.\mathrm{F}_{1,31}=15.19 ; p<0.05\right)$ and was higher in colluvial soils throughout the incubation (Figure 3). At the end of incubation, cumulative $\mathrm{CO}_{2}-\mathrm{C}$ in manure and combined-treated soils was five and three fold the amount of that in urea-treated soils, respectively.

Urea fertilization induced an increase in SOC mineralization for both locations (Table 4). It can be assumed that additional amounts of respired $\mathrm{C}$ originated from soil-derived carbon (positive PE). This is due to the fact that MBC decreased even more in control soils (592 \pm 54 $\mathrm{SE}$ and $318 \mathrm{mg} \cdot \mathrm{kg}^{-1} \pm 30 \mathrm{SE}$ at day 0 and 28 , respectively) compared to urea-treated soils $(418 \pm 44 \mathrm{SE}$ and $299 \mathrm{mg} \cdot \mathrm{kg}^{-1} \pm 34 \mathrm{SE}$ at day 0 and 28 , respectively). In contrast to day 2 - 7, a PE could not be calculated for the first day, since the respired $\mathrm{CO}_{2}-\mathrm{C}$ in the urea-treated soils did not exceed the $82 \%$ of the applied urea-C (Table 4). Particularly during day 2 - 7 a positive $\mathrm{PE}$ of 107 and $114 \%$ compared to soil-derived $\mathrm{CO}_{2}-\mathrm{C}$ of control soils was found in colluvial and eroded soils, respectively. However, from week three on differences in respiration between control and urea-treated soils were no longer significant.

\subsection{Influence of Different Fertilizer Treatments on Soil Microbial Properties}

PCA at day 0 showed a clear separation of different fertilizer treatments and the control soil along both axes (Figure 4(a)) with a dominance of the effects of the treatment over location. Two different dynamics became apparent at day 0 . This was illustrated by the first Principal Component (PC1) which showed a significant negative correlation with $\mathrm{MBC}$ and $\mathrm{MBN}(\mathrm{r}=-0.97$ and 


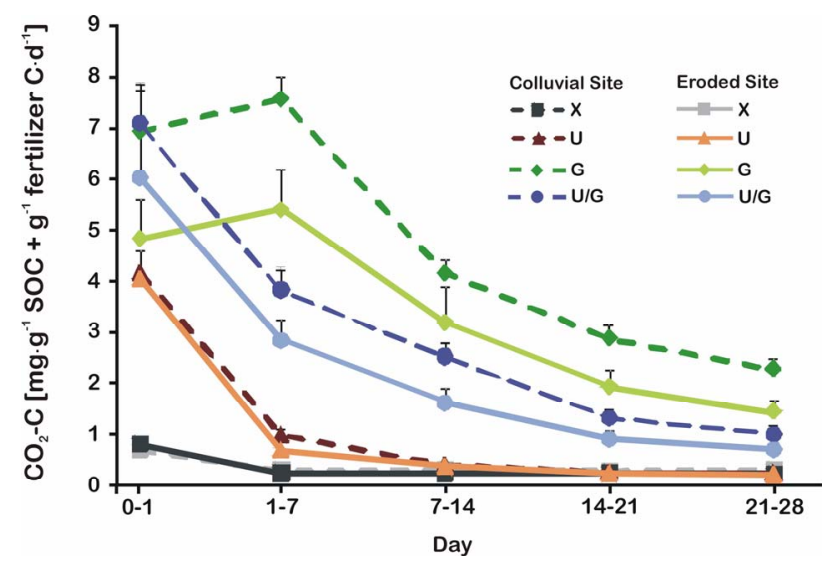

Figure 3. C mineralization rates per day in colluvial and eroded sites after different fertilizer treatment. The capital letters signify the following treatment: $X=$ control, $U=$ urea, $U / G=$ combined fertilization and $\mathrm{G}=$ guinea pig manure $(\mathrm{n}=5$, bars represent standard error). Results (F-values and significance) of repeated measures two-way factorial ANOVA are shown. They test the effects of treatment and location at different days of incubation on $\mathrm{CO}_{2}-\mathrm{C}$ production rates per day (Error degrees of freedom $\left.(\mathrm{DF})=124 ;{ }^{*} p<0.05,{ }^{* *} p<0.01,{ }^{* * *} p<0.001\right)$.

Table 4. Cumulative respiration of control and urea-treated soils at different locations (colluvial and eroded) within the temporal resolution of the measuring periods $(n=5)$. Calculation of PEs in mg CO $\mathrm{CO}_{2}-\mathrm{C} \mathrm{kg}^{-1}$ was based on the assumption that $82 \%$ of the initial urea-derived $\mathrm{CO}_{2}-\mathrm{C}\left(73.8 \mathrm{mg} \cdot \mathrm{kg}^{-1}\right)$ had been mineralized after 1 day [25].

\begin{tabular}{|c|c|c|c|c|}
\hline & \multirow[b]{2}{*}{ Day } & \multicolumn{3}{|c|}{ Respired $\mathrm{CO}_{2}-\mathrm{C}\left[\mathrm{mg} \cdot \mathrm{kg}^{-1}\right]$} \\
\hline & & Control & Urea & $\begin{array}{l}\text { Priming } \\
\text { Effect }\end{array}$ \\
\hline \multirow{6}{*}{ 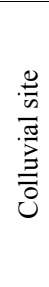 } & $0-1$ & $10.2(2.1)$ & $57.4(4.7)^{* * *}$ & \\
\hline & $2-7$ & $24.9(4.3)$ & $78.3(4.1)^{* * *}$ & $26.7(4.7)$ \\
\hline & $8-14$ & $27.4(3.6)$ & $38.0(4.5)$ & $10.6(2.4)$ \\
\hline & $15-21$ & $28.9(5.2)$ & $24.0(3.4)$ & $-4.9(1.9)$ \\
\hline & $22-28$ & $30.6(4.1)$ & $22.0(2.5)$ & $-8.6(2.1)$ \\
\hline & $0-28$ & $122.0(18.5)$ & $219.7(15.2)^{* *}$ & $23.8(7.8)$ \\
\hline \multirow{6}{*}{ 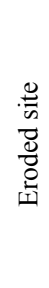 } & $0-1$ & $15.2(3.5)$ & $75.0(4.8)^{* * *}$ & \\
\hline & $2-7$ & $28.2(4.0)$ & $74.5(1.3)^{* * *}$ & $31.8(4.6)$ \\
\hline & $8-14$ & $33.4(4.4)$ & $47.6(2.3)^{*}$ & $14.3(3.5)$ \\
\hline & $15-21$ & $33.1(2.9)$ & $29.5(1.1)$ & $-3.5(2.7)$ \\
\hline & $22-28$ & $31.8(4.8)$ & $27.6(2.8)$ & $-4.2(3.3)$ \\
\hline & $0-28$ & $141.7(16.2)$ & $254.3(10.0)^{* * *}$ & $38.8(8.5)$ \\
\hline
\end{tabular}

$*{ }^{* *},{ }^{* * *}$ show statistical significance at the $0.05,0.01$ and 0.001 level, respectively.

-0.96 , respectively, $p<0.01$ ). Typically, manure-treated soils were linked with high contents of MBC and MBN. This effect seemed to be reinforced by the additional supply of phosphorus through manure amendment. In contrast, urea and combined-treated soils had a positive score on PC1 which was associated with a long arrow for
DON. Control soils were negatively correlated with respiration along $\mathrm{PC} 2$. This was related to higher concentrations of $\mathrm{H}_{3} \mathrm{O}^{+}$. Combined fertilizer treatment at day 0 was plotted close to long arrows of DOC and DON. Therefore, it marked an intermediate position between exclusive treatment with urea and manure which either displayed low amounts of DOC or DON, respectively (Figure 4(a)).

Except for manure-treated soils, differences between the particular treatments were less pronounced at day 28 compared to day 0 (Figure 4(b)). Both PCs clearly separated manure from all the other treatments. Control and urea-treated soils were plotted close to each other illustrating the short-term effect of the urea fertilization. In contrast, the scores of the combined fertilization were still associated with long arrows for $\mathrm{MBC}$ and $\mathrm{MBN}$ as well as inorganic nitrogen at day 28 (Figure 4(b)).

\section{DISCUSSION}

\subsection{Effects of $\mathbf{N}$ Fertilizer Type on $\mathbf{N}$ and $\mathbf{C}$ Cycling}

Fertilization with urea induced a rapid spike in mineral nitrogen (Figure 2) and soil carbon mineralization (Figure 3) in the first seven days of incubation as hypothesized. PEs associated with urea fertilization for soil $\mathrm{N}$ and SOC were less pronounced compared to similar studies $[25,54,55]$. This might be due to lower stocks of SOM (Table 1) compared to the studies mentioned above resulting in a reduced availability of SOM. Low recovery rates of ${ }^{15} \mathrm{~N}$ labeled urea in combined-treated soils (Table 3) can be a result of urea-immobilization after incorporation into the SMB $[22,25]$. This hypothesis is supported by the significant effect of the treatment on $\mathrm{MBC}$ and MBN (Table 2) as illustrated by an increased SMB in manure and combined-treated compared to urea-treated soils. This was consistent with other findings in tropical and subtropical regions $[56,57]$.

The results of the present study showed that addition of organic amendments induced positive effects on soil fertility which, however, need to be differentiated. Microbial immobilization of $\mathrm{N}$ after manure and combined treatment can result in an efficient and sustained release of $\mathrm{N}$ which plants could use throughout the entire growing season [58]. Additionally, microbial immobilization might reduce adverse environmental impacts such as leaching of nitrate or denitrification [16]. This is in clear contrast to urea treatment, where no N-incorporation into the MBN was detected suggesting an immediate and temporary $\mathrm{N}$-uptake by plants following urea application. On the other hand, amounts of $\mathrm{NH}_{4}-\mathrm{N}$ and $\mathrm{NO}_{3}-\mathrm{N}$ were very low in the incubated soil after manure amendment (Figure 2). This might cause a strong competition between soil microbes and plant roots for $\mathrm{N}$ sources as shown by a study of Marinari et al. [59]. This is 

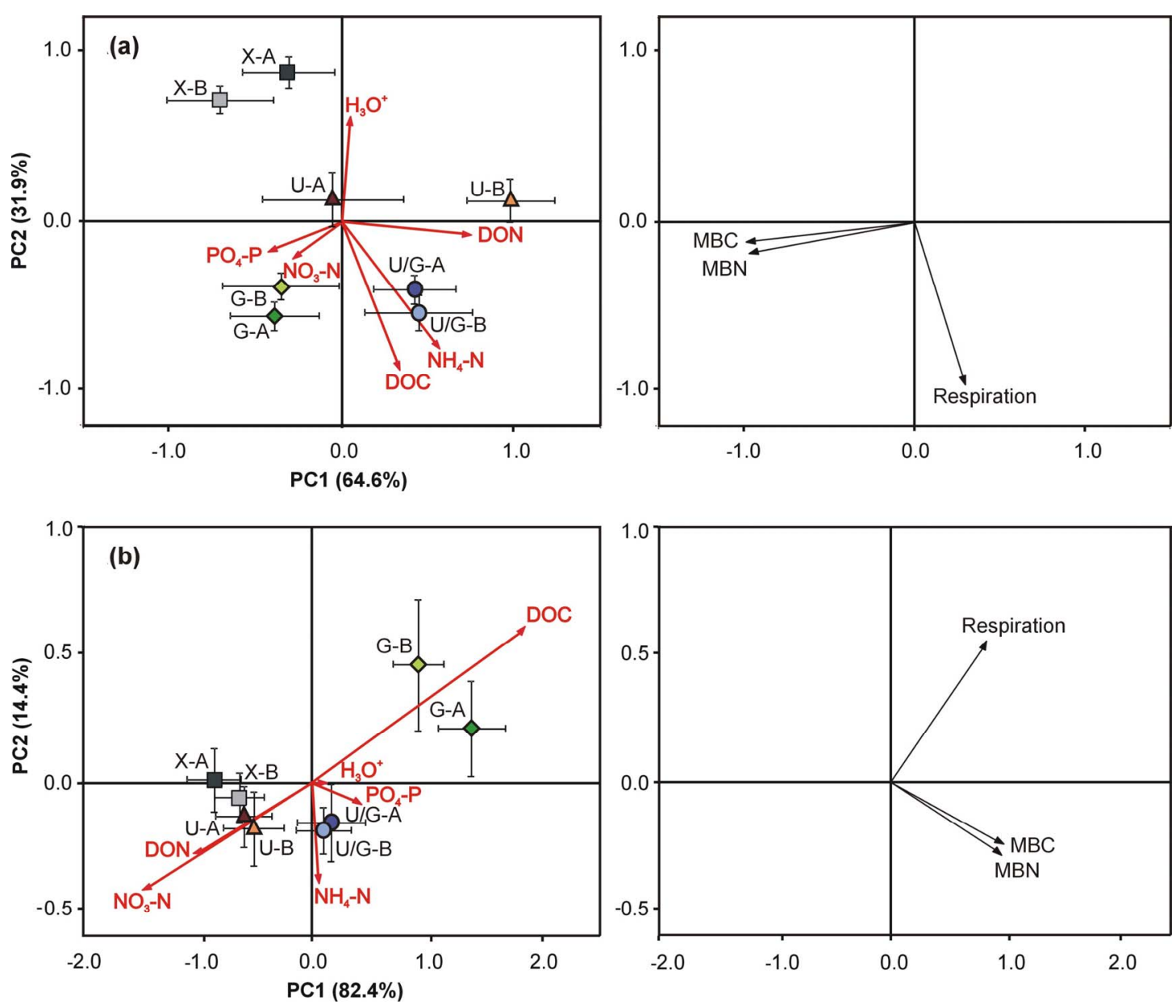

Figure 4. $P C A$ ordination diagrams for different fertilizer treatments $(X=$ control, $U=$ urea, $U / G=$ combined fertilization, $\mathrm{G}$ = guinea pig manure) in colluvial (capital letter "A") and eroded soils (capital letter "B"): (a) at day 0 (i.e. 15 minutes after fertilizer treatment and respiration data from day 1$)$ and (b) at day $28(\mathrm{n}=5$, bars indicate SE). Soil physical and chemical variables are marked with the red arrow. Response variables are presented on the right hand side.

supported by findings of Rees and Castle [60] who reported that soil microorganisms are more effective than the growing crop in the competition for mineral N. This is clearly a disadvantage of applying purely manure compared to the other treatments. In contrast, the ability of combined-treated soils to supply plant available $\mathrm{N}$ was indicated by the $\mathrm{PE}$ of soil-derived $\mathrm{NO}_{3}-\mathrm{N}$ which was in the same order of magnitude as for urea-treated soils (Figure 2). This was also found by Glendining et al. [21] after application of combined fertilizers.

An additional reason for low recovery rates could be the incorporation into the SOM fraction [61] which was proved for tropical soils in Indonesia [62] and Western Africa [63], respectively. A long-term study by Devevre and Horwath [64] illustrated an increased stabilization of fertilizer $\mathrm{N}$ into SOM 160 days after rice straw addition compared to soils solely treated with $\left(\mathrm{NH}_{4}\right)_{2} \mathrm{SO}_{4}$. Therefore, comparable beneficial effects can be expected from the amendment of manure. This is corroborated by the significant increase of the $\mathrm{MBC} / \mathrm{SOC}$ ratio after manure amendment since $\mathrm{MBC}$ is a sensitive indicator with regard to residue management change $[65,66]$. The PCA pointed out, that additional input of phosphorus after treatment with manure also had a beneficial effect on microbial activity (Figure 4). It was shown [67] that this effect could even be reinforced by the reduction of the phosphorus sorption after organic amendment. Increased $\mathrm{pH}$ values immediately after manure amendment (significant effect of treatment in Table 2) could have influenced microbial activity and/or community structure, as was indicated by increased respiration, MBC and MBN for manure (Figure 4). This is corroborated by Rousk et al. [68] who reported that a higher $\mathrm{pH}$ value had a positive effect on the bacterial diversity and diverse effects on the abundance. In addition, nutrients in organic manures are not only released more slowly but they also persist in the soil for a longer period and for this reason ensure a longer residual effect compared to non-organic 
fertilizers $[69,70]$.

\subsection{Eroded versus Colluvial Soils}

The hypothesis that eroded soils contain less SOM and SMB when the topsoil $(0-10 \mathrm{~cm})$ is taken into account must be rejected since results of the present study exhibited the opposite (Table 1). A combination of factors seems responsible for results which are in contrast to the common doctrine where water erosion typically reduced SOM stocks in eroded upper slopes and induced an accumulation of SOM in depositional sites [71,72].

The light and labile fraction of the SOC is mainly dislocated by erosion [73]. Hence, there is a higher abundance of easily decomposable organic substances in the topsoils of the depositional sites [74] which was confirmed by higher SOC mineralization rates with regard to total SOC content in the colluvial soils (Figure 3). Additionally, results clearly elucidated that fertilization solely with urea induced positive PEs on SOC (Table 4) and soil $\mathrm{N}$ mineralization (Figure 2). These should be more pronounced in colluvial sites since they are managed intensively in a cash crop rotation system with high urea application rates. A positive PE of $23 \mathrm{~kg} \cdot \mathrm{ha}^{-1}$ of soil $\mathrm{NO}_{3}-\mathrm{N}$ was detected 28 days after application of $200 \mathrm{~kg}$ urea-N $\cdot \mathrm{ha}^{-1}$ (Figure 2). Therefore, priming after application of urea should be considered as an important factor in lower SOM stocks of colluvial sites. Fontaine et al. [75] also found that the application of organic $\mathrm{C}$ induced SOM decreases due to increased PEs which strongly depended on the availability of nutrients for soil microbes.

Another driving factor for lower SOM stocks in the colluvial sites is the regular tillage since this is known to enhance SOC and soil N mineralization [76]. Apart from processes in colluvial soils, the concept of dynamic replacement [77] in the biologically active upper layers of eroded soils by fixation of new photosynthate could also be responsible for high SOC and TN stocks in eroded soils. Summarizing, it can be stated that the above-described processes outbalanced the SOC enrichment by deposited soil and hence, caused a depletion of SOC in the topsoil of colluvial sites. However, subsoils of colluvial sites are usually enriched in SOC at depth compared to those of eroded sites [74,78].

Based on SOC and TN, respiration rates (Figure 3) as well as $\mathrm{NO}_{3}-\mathrm{N}$ releases (Figure 2) were higher in colluvial soils. This is in compliance with a generally higher $q \mathrm{CO}_{2}$ for all fertilizer treatments in colluvial soils. Thus, these results indicate lower substrate-use efficiency [79] or a higher maintenance carbon demand [80] of the colluvial soils compared to those in eroded sites. This is also confirmed by the lower recovery rate of ${ }^{15} \mathrm{~N}$ in colluvial soils after combined fertilizer treatment. Increased soil moisture, as found in the colluvial soils, $(19 \%$ vs. $16 \%$ for eroded soils) induced an acceleration of the decomposition and resulted in high basal respiration and metabolic quotients in arid soils [81]. Sampling took place during the end of the rainy season where irrigation is not necessary. Therefore, this effect should even be more pronounced during the dry season, when the intensively managed foot slope soils are irrigated as opposed to the eroded upper slopes.

\section{CONCLUSION}

Fertilization with urea led to a decrease in soil microbial biomass and accelerated soil organic carbon and nitrogen mineralization (positive priming effects) in the investigated soils. This effect proved to be partly responsible for lower soil organic matter stocks in colluvial soils compared to eroded soils due to their intensive management with high urea application rates. The combined fertilization provided several benefits compared to the other treatments. Soil microbial biomass increased and plant available nitrogen was provided immediately. Results suggested the immobilization of fertilized nitrogen by the soil microbial biomass inducing an efficient and sustained release of nitrogen throughout the growing season. Additionally, increased $\mathrm{MBC} / \mathrm{SOC}$ ratios implied a long-term increase in soil organic carbon after guinea pig manure treatment. Since results only gave an insight into short-term effects, monitoring of the long-term effects after urea and manure fertilization on soil carbon and nitrogen dynamics was suggested. The implementation of field trials and investigation of plant-soil related processes would enable the derivation of site specific management strategies.

\section{ACKNOWLEDGEMENTS}

The authors would like express their thanks to Oene Oenema for fruitful comments and suggestions on the manuscript. We are also grateful for the helpful comments of Karin Potthast, Alexander Tischer and Philipp Baumgart. We thank the students for the assistance in the field work and Manuela Unger for the skilful laboratory work. Special thanks go to the farmers from Catamayo for their productive cooperation. The research was funded by the German Foundation of Research (DFG) in the project B2.1 (HA 4597/1-1) within the DFG Research Unit 816.

\section{REFERENCES}

[1] Mader, P., Fliessbach, A., Dubois, D., Gunst, L., Fried, P. and Niggli, U. (2002) Soil fertility and biodiversity in organic farming. Science, 296, 1694-1697. http://dx.doi.org/10.1126/science. 1071148

[2] Diacono, M. and Montemurro, F. (2010) Long-term effects of organic amendments on soil fertility. A review. Agronomy for Sustainable Development, 30, 401-422. http://dx.doi.org/10.1051/agro/2009040 
[3] Giller, K.E., Beare, M.H., Lavelle, P., Izac, A.M.N. and Swift, M.J. (1997) Agricultural intensification, soil biodiversity and agroecosystem function. Applied Soil Ecology, 6, 3-16.

http://dx.doi.org/10.1016/S0929-1393(96)00149-7

[4] Lal, R. (2001) Soil degradation by erosion. Land Degradation \& Development, 12, 519-539. http://dx.doi.org/10.1002/ldr.472

[5] Lal, R. (2004) Carbon sequestration in dryland ecosystems. Environmental Management, 33, 528-544. http://dx.doi.org/10.1007/s00267-003-9110-9

[6] Harden, C.P. (1991) Andean Soil Erosion: A comparison of soil erosion conditions in two Andean watersheds. $\mathrm{Na}$ tional Geographic Research \& Exploration, 7, 216-231.

[7] De Noni, G., Viennot, M. and Trujillo, G. (1996) Agricultural erosion in the Ecuadorian Andes. A natural and historical phenomenon. In: Roose, E., Ed., Land HusbandryComponents and Strategy, Food and Agriculture Organization of the United Nations (FAO), Rome, 321-329.

[8] Stoorvogel, J.J. and Smaling, E.M.A. (1998) Research on soil fertility decline in tropical environments: Integration of spatial scales. Nutrient Cycling in Agroecosystems, 50, 151-158. http://dx.doi.org/10.1023/A:1009732126336

[9] Smaling, E.M.A. and Dixon, J. (2006) Adding a soil fertility dimension to the global farming systems approach, with cases from Africa. Agriculture Ecosystems \& Environment, 116, 15-26.

http://dx.doi.org/10.1016/j.agee.2006.03.010

[10] Haileslassie, A., Priess, J., Veldkamp, E., Teketay, D. and Lesschen, J.P. (2005) Assessment of soil nutrient depletion and its spatial variability on smallholders' mixed farming systems in Ethiopia using partial versus full nutrient balances. Agriculture Ecosystems \& Environment, 108, 1-16. http://dx.doi.org/10.1016/j.agee.2004.12.010

[11] Tan, Z.X., Lal, R. and Wiebe, K.D. (2005) Global soil nutrient depletion and yield reduction. Journal of Sustainable Agriculture, 26, 123-146. http://dx.doi.org/10.1300/J064v26n01_10

[12] De Koning, G.H.J., Van de Kop, P.J. and Fresco, L.O. (1997) Estimates of sub-national nutrient balances as sustainability indicators for agro-ecosystems in Ecuador. Agriculture Ecosystems \& Environment, 65, 127-139. http://dx.doi.org/10.1016/S0167-8809(97)00059-5

[13] Borbor-Cordova, M.J., Boyer, E.W., McDowell, W.H. and Hall, C.A. (2006) Nitrogen and phosphorus budgets for a tropical watershed impacted by agricultural land use: Guayas, Ecuador. Biogeochemistry, 79, 135-161. http://dx.doi.org/10.1007/s10533-006-9009-7

[14] Van der Velde, M., See, L. and Fritz, S. (2012) Agriculture: Soil remedies for small-scale farming. Nature, $\mathbf{4 8 4}$, 318. http://dx.doi.org/10.1038/484318c

[15] Oenema, O., Janssen, B.H., Smaling, E. and Hoffland, E. (2006) Nutrient management in tropical agroecosystems. Agriculture Ecosystems \& Environment, 116, 1-3. http://dx.doi.org/10.1016/j.agee.2006.03.008

[16] Adesemoye, A.O. and Kloepper, J.W. (2009) Plant-microbes interactions in enhanced fertilizer-use efficiency Applied Microbiology and Biotechnology, 85, 1-12. http://dx.doi.org/10.1007/s00253-009-2196-0

[17] Ouedraogo, E., Mando, A., Brussaard, L. and Stroosnijder, L. (2007) Tillage and fertility management effects on soil organic matter and sorghum yield in semi-arid West Africa. Soil \& Tillage Research, 94, 64-74. http://dx.doi.org/10.1016/j.still.2006.07.001

[18] Palm, C.A., Gachengo, C.N., Delve, R.J., Cadisch, G. and Giller, K.E. (2001) Organic inputs for soil fertility management in tropical agroecosystems: Application of an organic resource database. Agriculture Ecosystems \& Environment, 83, 27-42. http://dx.doi.org/10.1016/S0167-8809(00)00267-X

[19] Huang, Z.Q., Xu, Z.H. and Chen, C.R. (2008) Effect of mulching on labile soil organic matter pools, microbial community functional diversity and nitrogen transformations in two hardwood plantations of subtropical Australia. Applied Soil Ecology, 40, 229-239.

http://dx.doi.org/10.1016/j.apsoil.2008.04.009

[20] Kuzyakov, Y., Friedel, J.K. and Stahr, K. (2000) Review of mechanisms and quantification of priming effects. Soil Biology \& Biochemistry, 32, 1485-1498.

http://dx.doi.org/10.1016/S0038-0717(00)00084-5

[21] Glendining, M.J., Poulton, P.R., Powlson, D.S. and Jenkinson, D.S. (1997) Fate of N-15-labelled fertilizer applied to spring barley grown on soils of contrasting nutrient. Plant and Soil, 195, 83-98. http://dx.doi.org/10.1023/A:1004295531657

[22] Abe, T., Katayama, A. and Watanabe, A. (2007) Temporal changes in distribution and composition of $\mathrm{N}$ from labeled fertilizer in soil organic matter fractions. Biology and Fertility of Soils, 43, 427-435. http://dx.doi.org/10.1007/s00374-006-0120-7

[23] Adesemoye, A.O., Torbert, H.A. and Kloepper, J.W. (2010) Increased plant uptake of nitrogen from N-15-depleted fertilizer using plant growth-promoting rhizobacteria. Applied Soil Ecology, 46, 54-58.

http://dx.doi.org/10.1016/j.apsoil.2010.06.010

[24] Potthast, K., Hamer, U. and Makeschin, F. (2012) In an Ecuadorian pasture soil the growth of Setaria sphacelata, but not of soil microorganisms, is co-limited by $\mathrm{N}$ and $\mathrm{P}$. Applied Soil Ecology, 62, 103-114. http://dx.doi.org/10.1016/j.apsoil.2012.08.003

[25] Hamer, U., Potthast, K. and Makeschin, F. (2009) Urea fertilisation affected soil organic matter dynamics and microbial community structure in pasture soils of Southern Ecuador. Applied Soil Ecology, 43, 226-233. http://dx.doi.org/10.1016/j.apsoil.2009.08.001

[26] Kukal, S.S., Rehana, R. and Benbi, D.K. (2009) Soil organic carbon sequestration in relation to organic and inorganic fertilization in rice-wheat and maize-wheat systems. Soil \& Tillage Research, 102, 87-92. http://dx.doi.org/10.1016/j.still.2008.07.017

[27] Hai, L., Li, X.G., Li, F.M., Suo, D.R. and Guggenberger, G. (2010) Long-term fertilization and manuring effects on physically-separated soil organic matter pools under a wheat-wheat-maize cropping system in an arid region of China. Soil Biology \& Biochemistry, 42, 253-259. http://dx.doi.org/10.1016/j.soilbio.2009.10.023

[28] Alemu, G. and Bayu, W. (2005) Effects of farmyard ma- 
nure and combined $\mathrm{N}$ and $\mathrm{P}$ fertilizer on sorghum and soil characteristics in northeastern Ethiopia. Journal of Sustainable Agriculture, 26, 23-41. http://dx.doi.org/10.1300/J064v26n02 04

[29] Zimmerer, K.S. and Langstroth, R.P. (1993) PhysicalGeography of tropical Latin-America-The spatial and temporal heterogeneity of environments. Singapore Journal of Tropical Geography, 14, 157-172. http://dx.doi.org/10.1111/j.1467-9493.1993.tb00046.x

[30] Garcia Ventocilla, D., Mamani Gamarra, G., Roman Cabello, N., Suarez Salas, L., Contreras Marin, A. and Malca Jauregui, J. (2011) Effect of addition of organic matter on bacterial population dynamics of soil in potato and corn crops. Revista Peruana de Biologia, 18, 355-360.

[31] Gonzalez, A. and Cantosaenz, M. (1993) Comparison of 5 organic amendments for the control of Globodera-Pallida in microplots in Peru. Nematropica, 23, 133-139.

[32] Garfi, M., Gelman, P.R., Comas, J., Carrasco, W. and Ferrer, I. (2011) Agricultural reuse of the digestate from low-cost tubular digesters in rural Andean communities. Waste Management, 31, 2584-2589. http://dx.doi.org/10.1016/j.wasman.2011.08.007

[33] Dinesh, R., Srinivasan, V., Hamza, S. and Manjusha, A. (2010) Short-term incorporation of organic manures and biofertilizers influences biochemical and microbial characteristics of soils under an annual crop [Turmeric (Curcuma longa L.)]. Bioresource Technology, 101, 46974702. http://dx.doi.org/10.1016/j.biortech.2010.01.108

[34] Jacinthe, P.A., Shukla, M.K. and Ikemura, Y. (2011) Carbon pools and soil biochemical properties in manurebased organic farming systems of semi-arid New Mexico. Soil Use and Management, 27, 453-463. http://dx.doi.org/10.1111/j.1475-2743.2011.00369.x

[35] Abbasi, M.K. and Khizar, A. (2012) Microbial biomass carbon and nitrogen transformations in a loam soil amended with organic-inorganic $\mathrm{N}$ sources and their effect on growth and $\mathrm{N}$-uptake in maize. Ecological Engineering, 39, 123-132. http://dx.doi.org/10.1016/j.ecoleng.2011.12.027

[36] Bendix, J., Rollenbeck, R. and Palacios, W.E. (2004) Cloud detection in the Tropics-A suitable tool for climate-ecological studies in the high mountains of Ecuador. International Journal of Remote Sensing, 25, 4521-4540. http://dx.doi.org/10.1080/01431160410001709967

[37] FAO, IUSS and ISRIC (2006) World reference base for soil resources 2006. In: World Soil Resources Reports No. 103. Food and Agriculture Organization of the United Nations, Rome, 128.

[38] Litherland, M., Aspden, J. and Jemielita, R. (1995) The metamorphic belts of Ecuador. British Geological Survey, Nottingham.

[39] Tabatabai, M.A. and Bremner, J.M. (1970) Use of leco automatic 70-second carbon analyzer for total carbon analysis of soils. Soil Science Society of America Proceedings, 34, 608-610. http://dx.doi.org/10.2136/sssaj1970.03615995003400040 $\underline{020 x}$

[40] Bascomb, C.L. (1964) Rapid method for determination of cation-exchange capacity of calcareous and non-calcareous soils. Journal of the Science of Food and Agriculture, 15, 821-823. http://dx.doi.org/10.1002/jsfa.2740151201

[41] McKeague, J.A. and Day, D.H. (1966) Dithionite- and oxalate-extractable $\mathrm{Fe}$ and $\mathrm{Al}$ as aids in differentiating various classes of soils. Canadian Journal of Soil Science, 46, 13-22. http://dx.doi.org/10.4141/cjss66-003

[42] Bray, R.H. and Kurtz, L.T. (1945) Determination of total, organic, and available forms of phosphorus in soil. Soil Science, 59, 39-45. http://dx.doi.org/10.1097/00010694-194501000-00006

[43] Guo, L.B., Cowie, A.L., Montagu, K.D. and Gifford, R.M. (2008) Carbon and nitrogen stocks in a native pasture and an adjacent 16-year-old Pinus radiata D. Don. plantation in Australia. Agriculture Ecosystems \& Environment, 124, 205-218. http://dx.doi.org/10.1016/j.agee.2007.09.013

[44] Schlichting, E., Blume, H.-P. and Stahr, K. (1995) Bodenkundliches Praktikum. Blackwell Wissenschaftsverlag, Berlin.

[45] Irshad, M., Yamamoto, S., Eneji, A.E., Endo, T. and Honna, T. (2002) Urea and manure effect on growth and mineral contents of maize under saline conditions. Journal of Plant Nutrition, 25, 189-200. http://dx.doi.org/10.1081/PLN-100108790

[46] Yousif, A.M. and Mubarak, A.R. (2009) Variations in nitrogen mineralization from different manures in semiarid tropics of Sudan with reference to salt-affected soils. International Journal of Agriculture and Biology, 11, 515520.

[47] Vance, E.D., Brookes, P.C. and Jenkinson, D.S. (1987) An extraction method for measuring soil microbial biomass-C. Soil Biology \& Biochemistry, 19, 703-707. http://dx.doi.org/10.1016/0038-0717(87)90052-6

[48] Martens, R. (1995) Current methods for measuring microbial biomass-C in soil-Potentials and limitations. $B i$ ology and Fertility of Soils, 19, 87-99. http://dx.doi.org/10.1007/BF00336142

[49] Jenkinson, D.S., Brookes, P.C. and Powlson, D.S. (2004) Measuring soil microbial biomass. Soil Biology \& Biochemistry, 36, 5-7. http://dx.doi.org/10.1016/j.soilbio.2003.10.002

[50] Anderson, T.H. and Domsch, K.H. (1993) The metabolic quotient for $\mathrm{CO}_{2}\left(\mathrm{qCO}_{2}\right)$ as a specific activity parameter to assess the effects of environmental conditions, such as $\mathrm{pH}$, on the microbial biomass of forest soils. Soil Biology \& Biochemistry, 25, 393-395. http://dx.doi.org/10.1016/0038-0717(93)90140-7

[51] Mulvaney, R.L., Khan, S.A., Stevens, W.B. and Mulvaney, C.S. (1997) Improved diffusion methods for determination of inorganic nitrogen in soil extracts and water. $B i$ ology and Fertility of Soils, 24, 413-420. http://dx.doi.org/10.1007/s003740050266

[52] Ter Braak, C.J.F. and Smilauer, P. (2002) CANOCO reference manual and CanoDraw for Windows user's guide: Software for Canonical Community Ordination (version 4.5). Biometris, Wageningen.

[53] Cornell, R.M. and Schwertmann, U. (2003) The iron oxides: Structure, properties, reactions, occurrences and 
uses. Wiley-VCH, Weinheim.

[54] De Nobili, M., Contin, M., Mondini, C. and Brookes, P.C. (2001) Soil microbial biomass is triggered into activity by trace amounts of substrate. Soil Biology \& Biochemistry, 33, 1163-1170. http://dx.doi.org/10.1016/S0038-0717(01)00020-7

[55] Blagodatskaya, E.V., Blagodatsky, S.A., Anderson, T.H. and Kuzyakov, Y. (2007) Priming effects in Chernozem induced by glucose and $\mathrm{N}$ in relation to microbial growth strategies. Applied Soil Ecology, 37, 95-105.

http://dx.doi.org/10.1016/j.apsoil.2007.05.002

[56] Banger, K., Kukal, S.S., Toor, G., Sudhir, K. and Hanumanthraju, T.H. (2009) Impact of long-term additions of chemical fertilizers and farm yard manure on carbon and nitrogen sequestration under rice-cowpea cropping system in semi-arid tropics. Plant and Soil, 318, 27-35. http://dx.doi.org/10.1007/s11104-008-9813-Z

[57] Yan, D.Z., Wang, D.J. and Yang, L.Z. (2007) Long-term effect of chemical fertilizer, straw, and manure on labile organic matter fractions in a paddy soil. Biology and Fertility of Soils, 44, 93-101. http://dx.doi.org/10.1007/s00374-007-0183-0

[58] Dodd, I.C. and Ruiz-Lozano, J.M. (2012) Microbial enhancement of crop resource use efficiency. Current Opinion in Biotechnology, 23, 236-242. http://dx.doi.org/10.1016/j.copbio.2011.09.005

[59] Marinari, S., Badalucco, L., DeToledo, V.C. and Grego, S. (1996) Effect of composted manure on soil fertility and maize (Zea mays) production: Preliminary results. Agrochimica, 40, 276-283.

[60] Rees, R. and Castle, K. (2002) Nitrogen recovery in soils amended with organic manures combined with inorganic fertilisers. Agronomie, 22, 739-746. http://dx.doi.org/10.1051/agro:2002061

[61] Bremer, E. and Van Kessel, C. (1992) Seasonal microbial biomass dynamics after addition of lentil and wheat residues. Soil Science Society of America Journal, 56, 11411146.

http://dx.doi.org/10.2136/sssaj1992.03615995005600040 $\underline{022 x}$

[62] Abe, T., Suwandhi, S.S., Ardjasa, W.S., Ando, H. and Watanabe, A. (2002) Incorporation of nitrogen from urea fertilizer into soil organic matter in rice paddy and cassava upland fields in Indonesia. Soil Science and Plant Nutrition, 48, 825-832. http://dx.doi.org/10.1080/00380768.2002.10408708

[63] Ibewiro, B., Sanginga, N., Vanlauwe, B. and Merckx, R. (2000) Transformations and recovery of residue and fertilizer nitrogen-15 in a sandy lixisol of West Africa. Biology and Fertility of Soils, 31, 261-269. http://dx.doi.org/10.1007/s003740050655

[64] Devevre, O.C. and Horwath, W.R. (2001) Stabilization of fertilizer nitrogen-15 into humic substances in aerobic vs. waterlogged soil following straw incorporation. Soil Science Society of America Journal, 65, 499-510. http://dx.doi.org/10.2136/sssaj2001.652499x

[65] Galdos, M.V., Cerri, C.C. and Cerri, C.E.P. (2009) Soil carbon stocks under burned and unburned sugarcane in
Brazil. Geoderma, 153, 347-352. http://dx.doi.org/10.1016/j.geoderma.2009.08.025

[66] Sparling, G.P. (1992) Ratio of microbial biomass carbon to soil organic-carbon as a sensitive indicator of changes in soil organic-matter. Australian Journal of Soil Research, 30, 195-207.

http://dx.doi.org/10.1071/SR9920195

[67] Nziguheba, G., Palm, C.A., Buresh, R.J. and Smithson, P.C. (1998) Soil phosphorus fractions and adsorption as affected by organic and inorganic sources. Plant and Soil, 198, 159-168. http://dx.doi.org/10.1023/A:1004389704235

[68] Rousk, J., Baath, E., Brookes, P.C., Lauber, C.L., Lozupone, C., Caporaso, J.G., Knight, R. and Fierer, N. (2010) Soil bacterial and fungal communities across a $\mathrm{pH}$ gradient in an arable soil. Isme Journal, 4, 1340-1351. http://dx.doi.org/10.1038/ismej.2010.58

[69] Eghball, B. (2002) Soil properties as influenced by phosphorus- and nitrogen-based manure and compost applications. Agronomy Journal, 94, 128-135. http://dx.doi.org/10.2134/agronj2002.0128

[70] Sharma, A.R. and Mittra, B.N. (1991) Effect of different rates of application of organic and nitrogen fertilizers in a rice-based cropping system. Journal of Agricultural Science, 117, 313-318. http://dx.doi.org/10.1017/S0021859600067046

[71] Liu, S.G., Bliss, N., Sundquist, E. and Huntington, T.G. (2003) Modeling carbon dynamics in vegetation and soil under the impact of soil erosion and deposition. Global Biogeochemical Cycles, 17, 1074. http://dx.doi.org/10.1029/2002GB002010

[72] Lal, R. (2003) Soil erosion and the global carbon budget. Environment International, 29, 437-450. http://dx.doi.org/10.1016/S0160-4120(02)00192-7

[73] Gregorich, E.G., Greer, K.J., Anderson, D.W. and Liang, B.C. (1998) Carbon distribution and losses: Erosion and deposition effects. Soil \& Tillage Research, 47, 291-302. http://dx.doi.org/10.1016/S0167-1987(98)00117-2

[74] Doetterl, S., Six, J., Van Wesenael, B. and Van Oost, K. (2012) Carbon cycling in eroding landscapes: Geomorphic controls on soil organic C pool composition and C stabilization. Global Change Biology, 18, 2218-2232. http://dx.doi.org/10.1111/j.1365-2486.2012.02680.x

[75] Fontaine, S., Henault, C., Aamor, A., Bdioui, N., Bloor, J.M.G., Maire, V., Mary, B., Revaillot, S. and Maron, P.A. (2011) Fungi mediate long term sequestration of carbon and nitrogen in soil through their priming effect. Soil Biology \& Biochemistry, 43, 86-96.

http://dx.doi.org/10.1016/j.soilbio.2010.09.017

[76] Pandey, C.B., Chaudhari, S.K., Dagar, J.C., Singh, G.B. and Singh, R.K. (2010) Soil N mineralization and microbial biomass carbon affected by different tillage levels in a hot humid tropic. Soil \& Tillage Research, 110, 33-41. http://dx.doi.org/10.1016/j.still.2010.06.007

[77] Harden, J.W., Sharpe, J.M., Parton, W.J., Ojima, D.S., Fries, T.L., Huntington, T.G. and Dabney, S.M. (1999) Dynamic replacement and loss of soil carbon on eroding cropland. Global Biogeochemical Cycles, 13, 885-901. 
http://dx.doi.org/10.1029/1999GB900061

[78] Vandenbygaart, A.J., Kroetsch, D., Gregorich, E.G. and Lobb, D. (2012) Soil C erosion and burial in cropland. Global Change Biology, 18, 1441-1452. http://dx.doi.org/10.1111/j.1365-2486.2011.02604.x

[79] Anderson, T.H. and Domsch, K.H. (1990) Application of ecophysiological quotients (qCO2 and qD) on microbial biomasses from soils of different cropping histories. Soil Biology \& Biochemistry, 22, 251-255.
http://dx.doi.org/10.1016/0038-0717(90)90094-G

[80] Anderson, T.-H. and Domsch, K.H. (2010) Soil microbial biomass: The eco-physiological approach. Soil Biology \& Biochemistry, 42, 2039-2043.

http://dx.doi.org/10.1016/j.soilbio.2010.06.026

[81] Insam, H. (1990) Are the soil microbial biomass and basal respiration governed by the climatic regime. Soil Biology \& Biochemistry, 22, 525-532. http://dx.doi.org/10.1016/0038-0717(90)90189-7 